\title{
The Dictum, Igbo Enwe Eze (Igbo Has No King): Socio-Cultural Underpinnings for Understanding the Current Igbo Peoples' Political Dilemma
}

\author{
Michael Onyedika Nwalutu \\ Social Justice Education, OISE, University of Toronto, Toronto, Canada \\ Email: nwalutu@yahoo.co.uk
}

How to cite this paper: Nwalutu, M. O. (2019). The Dictum, Igbo Enwe Eze (Igbo Has No King): Socio-Cultural Underpinnings for Understanding the Current Igbo Peoples' Political Dilemma. Sociology Mind, 9, 86-94.

https://doi.org/10.4236/sm.2019.91005

Received: October 25, 2018

Accepted: December 1, 2018

Published: December 4, 2018

Copyright $\odot 2019$ by author and Scientific Research Publishing Inc. This work is licensed under the Creative Commons Attribution International License (CC BY 4.0).

http://creativecommons.org/licenses/by/4.0/

\section{(c) (i) Open Access}

\begin{abstract}
This piece examines the Igbo as a nation of many indigenous egalitarian societies and critically, albeit succinctly reviews contributions of renowned scholars, historians, and socio-cultural custodians, from historical and socio-political perspectives, and within the context of colonization; in order to tease out the cardinal cultural pillars upon which the Igbo enwe eze aphorism is anchored. This submission is critical to the understanding of Igbo as a people and how colonization and neo-colonial vestiges had corroded (and therefore weakened) and continues to erode the cultural norms, values and mores that are pivotal to the peoples' socio-cultural epistemic saliencies (lived experiences). The submission foregrounds the current "weakness" in the Igbo peoples' political dynamics in Nigeria or elsewhere in the world, in the denotation of the esoteric usage, Igbo enwe eze.
\end{abstract}

\section{Keywords}

Igbo, King, Axiom, Dilemma, Eze, Politics, Culture

\section{Introduction}

In this piece, the Igbo as a nation of many Indigenous egalitarian societies is examined critically albeit succinctly, from historical and socio-political perspectives, and within the context of colonization; in order to tease out the cardinal cultural pillars upon which the Igbo enwe eze aphorism is anchored. This submission is critical to the understanding of Igbo as a people and how colonization and neo-colonial vestiges had corroded (and therefore weakened) and continues to erode the cultural norms, values and mores that are pivotal to the peoples' so- 
cio-cultural epistemic saliencies (lived experiences). The submission foregrounds the current "weakness" in the Igbo peoples' political dynamics in Nigeria or elsewhere in the world, in the denotation of the esoteric usage, Igbo enwe eze. While it is imperative to adduce from the title that the Igbo peoples pre- and post-history had leaders; the socio-cultural principles and praxis prevalent in their societies availed no room for rulers. The title does not therefore suggest or imply the non-existence of leadership positions such as chiefs (by whatever title they are known) in Igbo societies, it only unequivocally points to the non-existence of dynasty of rulers or a ruler (monarch) who wields absolute power as obtained in many other societies of precolonial Africa. Igbo peoples believe in and practiced "raw democracy", which implies that every Igbo citizen doubles as a King and King-maker. No single member of the society imposes her/himself on the rest as the custodian of absolute power. Igbo people believe that absolute power resides with only one Being, the Chukwu (Almighty God) or Chineke (God the Creator). Hence you have an echelon of power descending from the Apex, inhabited by the Almighty God alone. Then He is attended by the deities (as mediators between the Creator and human), then the ancestors, deified humans, priests, diviners, NdiIchie or community elders, heroines and heroes, Nze and Ozortitle holders, various initiates of masquerade groups and various male and female age groups. It is vital to mention at this point that in many Igbo pre-colonial societies male and female members work coordinately (organize the society's complex systems in a way that the numerous people are involved and bring their contributions together to form a coherent or efficient whole; as opposed to subordinately) in ensuring that peace, equity, fairness and goodwill prevailed. This was one reason it was difficult for the Lord Lugard's colonial (imposed) indirect rule system, which succeeded in the other parts of the later federated entity called Nigeria to work among the Igbo societies. In fact the Igbo women's resistance against the British imposition of taxation on their male folks in 1929 was documented as a never-before-seen nationalist war.

\section{History of Origin: Whence the Igbo Nation}

The Igbo historiography as in those of other ethnic groups all over the world is strewn with varying and sometimes conflicting narratives as far as the origin of a people is concerned. And like other Indigenous peoples all over the globe, Igbo people in the continent of Africa and diasporas are compelled by emerging questions of identity, political and socio-cultural integration as well as desire for autonomy and right for self-determination, to investigate with a view to discovering their origin. Understanding their history-their past, equips them to appreciate the present-and grounds them to face the future. The quest for history of origin thus informs the need for the Igbo people to deconstruct existing colonial narratives, the essentialized version on how they have come to perceive themselves, and critically reconstruct how they became who they are. Igbo people's 
experiences under the British colonial administration (particularly, the documented tirade of the administrator, lord Fredrick Lugard against the Igbo) and the socio-political incidents since Nigeria's Independence have accentuated for them the import of re-inventing their group history and identity that would be authenticated, validated and documented in archives for posterity. Igboland covers most of Southeast Nigeria, a land bounded on all sides by peoples of other ethnic extractions including: the Bini, Warri, Ijaw, Ogoni, Igala, Tiv, Yako and Ibibio (Afigbo, 1975; Acholonu, 2010; Oriji, 1994; Isichei, 1983). Recent online submissions indicate that Igboland could be seen to be politically divided between several southern Nigerian states, which is conspicuously culturally categorized into several social groups that include: The Anioma, Ngwa, Edda Egbebu, Ezaa, Ibeku, Ohuhu, Omuma and the Ekpeye. Wikipedia cites William Balfour Baikie to have remarked that "in Igbo [land] each person hails, as a sailor would say, from the particular district where he was born, but when away from home all are Igbos. And yet considerable differences exist between different parts of this extensive country, and the dialects spoken also vary greatly" (Baikie, 1856).

Current literature is replete with varying accounts and nuanced narratives of the origins of the Igbo peoples, some verifiable and others pseudo-fictions. Outstanding among the vivid anthropological research is anchored in the three volumes of eminent Igbo academic luminary, Catherine Acholonu. In her works: The Gram Code of African Adam, book one, They Lived Before Adam, book two, The Lost Testament of the Ancestors of Adam, book three, Acholonu accentuates the cultural, anthropological and spiritual connections to the origins of human (Isichei, 1983; Talbot, 1926; Acholonu, 2010). She traced the origins of the Sumerians, the Egyptians, Hindu Kushites (East Indians), Hebrews, and Arabs through the narratives of human beginnings in Africa in which she delved into a pre-historic community in West Africa described in Egyptian records as Punt/Panchea; and in the Hebrew Bible, as Eden. Acholonu goes further to draw connection to an archeological excavation in West Africa by a British archaeologist in 1950, which was deemed an ancient city center known as Yebu or Igbo in local language (Acholonu, 2010). Another important but controversial explanation is that Igbo peoples are Jewish descendants of Gad, one of the sons of Jacob. Many raw evidences in cultural similarities, Biblical notations, archeological findings, and recently scientific evidences have been tabled on account of this. As much as histories of origin are often trailed by migration accounts evidence of man-made tools like axe, pottery and carved stones dug up at the present day Enugu and Ebonyi states tend to ground the historical credibility of the habitation of Igbo peoples in Igboland over a very long period (Slattery, 2010; Acholonu, 2005; Onwutalobi, 2015). With respect to the accounts on Igbo peoples' origin in relation to their initial inhabitants and early settlements, there are four outstanding narratives documented as: The Amaigbo, Owere, Awka, and Owere-Awka views. The fourth account, affirmed by the works of eminent African historians and anthropologists, is apparently better positioned to argue that 
the Igbo people living along the belt formed by the Owerri, Awka, Orlu and Okigwe divisions comprise the centre of Igbo evolution and dispersal.

\section{Igbo Enwe Eze Subsists}

The axiom Igbo enwe eze (literarily translated; Igbo has no king) is a phrase with both connotative and denotative implications, and is as much a political concept as it is social platitude. The usage has generated no small measure of polemics among scholars of Igbo political systems. In most discourses at conferences, workshops and other focus group for a it has attracted much thematic elaborations. Igbo enwe eze has been debated, theorized, and written about. Some scholars vilify the underlying assumption of those who believe the phrase is an honest articulation of Igbo Indigenous democratic system of governance. This opposing school of thought points at such organized precolonial leadership systems as obtained at the Nri and Aro societies of Igboland (Acholonu, 2005; Equiano, 1837). The proposing group always point at the Igbo as a nation and attempts to compare its socio-political systems with those of the other ethnic groups in $\mathrm{Ni}$ geria, and by extension African continent. This submission must not fail at this juncture to draw attention to the premise that many Igbo societies of the present bought the idea of chief, or eze (in whatever ascriptions, title or standard they are established) from colonial or imposed warrant chief system or through the intercultural relationships with the other ethnic groups in the entity called Nigeria (Acholonu, 2009; Baikie, 1856; Slattery, 2010; Afigbo, 1975). A little wonder, the dictum, Igbo enwe eze-an esoteric aphorism has so confused the new dispensation of Igbo political thinkers and scholars that they try to fight of its ubiquitous phantom using weapons of colonial vestiges grounded in the country's academe. Also "keen" observers of the political dynamics among the Igbo peoples in a broader Nigeria polity have raised erroneous alarm over the inability of Igbo peoples to speak as one voice in the national politics, and they have often advised the Ndi-Igbo to borrow a leaf from the socio-political relations among the other major ethnic groups in the federation. Whether or not these advises are well founded also depends on the outcome of a comprehensive analysis and appraisal of paradigm shifts in actual models of Igbo leadership styles, which is outside the scope of this submission. The questions that will guide the thrust of this reasoning are: How do the Igbo peoples in the country and diasporas successfully organize themselves into various macro and micro socio-political systems each grouped under leaders democratically elected by themselves? Why have similar efforts among the Igbos within Nigeria polity failed or been frustrated? While this submission does not intend to outline the numerous submissions and representations of all parties to this deliberation, it is anchored on the conviction that an understanding and appreciation of the political concept, Igbo enwe eze would better position the present and future Igbo peoples to decolonize and restructure the existing leadership systems fraught with dissension, disloyalty and insubordination; and begin to appreciate, appro- 
priate and further explore with the view to applying this enduring politically rich wisdom in their politics within the federate Nigeria system and beyond.

\section{Divergent and Convergent Predicaments: Colonization and the Corruption of Igbo Political Setups}

Divergent opinions, critiques, and views on Igbo enwe eze notwithstanding, a consensus is represented in the argument that the Igbo socio-political ideals of Eze (King) bears no etymological semblance to the ideas of the same concept outside Igboland. In other words Eze as operated among the Igbo does not equate King, Oba (as in Benin Kingdom in Mid-Western Nigeria, and Yoruba Kingdoms of Southern Nigeria) nor does the power attributed to "eze" Igbo comparable to those of the Emirs or Sultans in the Northern parts of Nigeria. Eze is not and has never been a monarch who wields absolute power over his subjects. In fact he is a "leader-servant" to the Igbo society of his extraction. It becomes necessary at this point to highlight that subversion of the Igbo Indigenous cultures (and by extension, those of other African nations); and the peoples' resistance to imposed cultures of the colonizer happen simultaneously at the intersections of pervasive colonial domination. Note that the effect of colonization in Africa, and with particular reference to Nigeria must not be limited to what the West did or failed to do. The erosion of many Nigerian languages and cultural values resulted from and continue to happen through subtle imposition of foreign socio-political and cultural ideologies on the Indigenous peoples. The Islamic colonial impact on Northern Nigeria as a form of cultural domination, which through the current regime in the country, is stealthily infiltrated into national educational curricula, has for about 400 hundred years before Western invasions exterminated the cultural heritages of the predominantly Hausa speaking peoples, replacing them with Arabic education, culture, and monarchical political systems. What therefore the locust (Arab/Islamic) colonization) left, the cankerworm (Western colonization) had eaten up, and what the Western colonization left, the palmerworm and caterpillars (Indo-Chinese) colonization is eating up. There is therefore no clear ground to raise the flag of Post-Colonial as is the case with many academic works, because even the logics of post-colonial itself is a denial of the evergreen but subtle chameleonic mutations inherent in the genes of colonization as a machinery of domination. Colonization simply does not end at the so-called independence of the colonized states-it is rather a continuum-for both the old colonizers and the emerging species continue to change or disguise their forms and strategies of empire and systems of capital expansion. Consequently, one is left in no doubts that if unchecked, it would not be long before few remaining cultural traits of the Igbo peoples and those of the other ethnic groups in the country will face their final extinction under the present insidious, clandestine, subversive invasions. At the moment, the Indo-Chinese colonization, like any other modern colonization strategy is an ominous threat to the remnants of the Nigerian peoples' Indigenous cultural values. Since language is the greatest tool of knowledge production, 
preservation, and validation, as well as the medium for dissemination of culture the disappearance of many of the known African peoples' Indigenous languages also signifies the complete erasure of the cultures from which those languages operated originally. As a result, it is not strange that many new generation Nigerians, with particular reference to the Igbo peoples who were born and raised under the tutelage of colonial education and cultures would subsume their Indigenous world views in the foreign cultures imposed on them by the colonizers. Those were unfortunately the heritages they grew up to know and are taught at the various levels of the dominant institutions of knowledge transmission. They learnt that their Indigenous cultural heritages were primitive, barbaric, and acts of paganism, and were systematically retuned to adopt and even propagate the foreign worldviews of their colonial lords. The validation, appropriation, and essentialization of the colonizers' cultural values leave most of the present Igbo peoples culturally and therefore environmentally irrelevant and unable to distinguish between the Indigenous cultures and those they inherited from the colonizers. Igbo enwe eze thus becomes both a symbol of Indigenous Igbo peoples' resistance to imposed norms, values and the mores as well as an affront to the internalized foreign world views that had established warrant chief system. The axiom, Igbo enwe eze goes far beyond connotative (sense connected to or suggested by the phrase) interpretation to a literal implication.

\section{A Wise Saying and Its Veracity}

It is unfortunate that many Igbo elites who have amassed foreign world views (or who are colonially acculturated) through education and travel; and a few Indigenous Igbo people who seek recognition as "modern" are coining up with another phrase, "Igbo nwereeze (Igbo has king). It is obviously a struggle to numb their feelings of the reality that the original wise saying represents. Nevertheless, Igbo enwe eze as a culturally rooted axiom in Igboland shares a deeply grounded philosophical genuineness, the neglect of which has left many present Igbo leaders groping for light to figure out how to swing their wand of leadership without losing their potentially disloyal subjects. For instance many Igbo chiefs and social association leaders have had their leadership crashed, and their chiefdoms or associations scattered after unsavory addresses they delivered in council meetings were met with, "to your tent" responses from the subjects or members of the groups. Such inexplicable disengagements have not only left the leaders involved wondering what went wrong, but incited keen observers of Igbo politics in Nigeria and elsewhere to reason that Igbo people are as difficult to rule as their language is to learners. It is more likely that Igbo enwe eze, which could be viewed in the lenses of other Igbo usages, like the riddles and jokes, names, parables and adages, idioms and parodies etc is not divorced from the people's experiential realities. Thus an Igbo leader (not ruler) who neglects Igbo enwe eze (as an advice) might risk disorganizing and ruining his chiefdom or association as $\mathrm{s} / \mathrm{he}$ may face resistance or outright absconding from the subjects or organization members respectively. 


\section{Conclusion}

\section{The Vested Power of Leadership Is with the People}

The power of social or political leadership in Igboland rests with the people individually and collectively, not on the leader, for it is the subjects who collectively grant authority to the leader and reserve the power to take the authority back. In other words, the authority to operate as a nominated leader of any Igbo social organization devolves to the post of the leader from the subjects, and the interests and opinions of the masses must be sort by the leader in matters of societal importance. Igbo enwe eze therefore does not negate the possibility of a leader (as opposed to a ruler) in most Igbo societies. It simply affirms the reality that no leader chosen by his people is allowed by the Igbo peoples' socio-political principles to wield absolute authority over the rest of the citizenry. Unlike the monarchical system among the Benin and Yoruba peoples of the Mid-Western and Western Nigeria for instance; in which the palace chiefs check and balance the king's decision when matters of socio-political nature is deliberated upon, the Igbo chief must consult with heads of the various socio-cultural groups under her/him. The idea is that in any socio-political consultation with other ethnic nationalities an Igbo leader (chief or Eze) is actually supposed to represent the people by presenting their collective opinions or views. To accomplish this task successfully, the Eze must have consulted with the head of religious bodies, that is the chief priests and oracle men, some of whom are deemed to bring the oracle of God and venerated ancestors to bear on the living. The leader must also have the final words of the following: the outcome of his deliberations with the NdiIchie (council of aged people men and women by whatever title they are known); the Nze and Ozor title holders; and leaders of the various age-groups. In other words, an Igbo leader is successful if s/he exhibits ingenuity and forthrightness in disposition, but also shrewd in information management and diplomacy. The leader wins the love of her/his subjects if $s /$ he is a champion of consultation, guru in data collection and critical analysis; adept in case and opinion review and resourceful with logistics. Series of consultations with heads or opinion leaders of the grass-root must be completed and analysis of the various contributions of members or subjects must be critically performed to arrive at a final decision or resolution, which becomes the single voice of the society represented. The Eze must summon the council of NdiIchie of the community to a final meeting and relay (as a matter of confirmation) all the views agreed upon. In his presentation the Eze or leader must address the members of his/her domain shifting between subject, object, possessive and first person pronoun (plural). Thus s/he says, Ibeanyi "our people", not my people, "we have agreed to tender this information, as our response to the demand placed on us by so, so, and so. The leader at this point seeks a reconfirmation on the agreed message. S/he would say, "and now you send me to deliver so, so and so message, our people, isn't it so?" The elders in council will respond, "Yah, obukaomelu", yes that was how it happened. At this point the leader knows that $s /$ he has the backing of the 
entire citizenry to proceed with the errand. Should there be a negative consequence or fallout from the errand, the Igbo community backs her/him up and the people are ready to collectively shoulder the consequences of the errand. Finally, the Eze title in Igbo depicts their religious belief that the only Being capable of receiving the attribute of "King" without reservation is not found among mortal human or the dead. The position of Eze (King), Igweka ala (the sky that is greater than earth, Okaa Omee, One who says and does as he said, etc belongs to the God Almighty (Chukwu) or God the creator (Chineke or Chiokike). Hence Igbo names like Chukwubueze or Chibueze (God Almighty is the King); Chukwumeremeze (God Almighty made me king). The variance is Chukwumaeze (God Almighty know who would be king, or is the kingmaker). Based on these notions if an Igbo leader is chosen and later be found to be self-willed, perverting justice, is tyrannical and undemocratic and imposes her/himself on fellow Igbo people or members of the socio-political association they collectively would refuse to take orders from her/him. They will become disloyal and insubordinate to the ruler and would derisively tell the ruler to be chief and rule her/his family.

\section{Conflicts of Interest}

The authors declare no conflicts of interest regarding the publication of this paper.

\section{References}

Acholonu, C. O. (2005). The Gram Code of the African Adam. Nigeria: CARC Publishing.

Acholonu, C. O. (2009). They Lived before Adam: Prehistoric Origins of the Igbo the Never-Been-Ruled.

Acholonu, C. O. (2010). The Lost Testamentof the Ancestors of Adam: Unearthing Heliopolis/Igbo Ukwu - The Celestial Cities of the Gods of Egypt and India). Abuja, Nigeria, CARC Publ.

Afigbo, A. E. (1975). Prolegomena to the Study of the Culture History of the Igbo-Speaking Peoples of Nigeria. Igbo Language and Culture, Oxford University Press.

Baikie, W. B. (1856). Narrative of an Exploring Voyage up the Rivers of Kwora and Binue Commonly Known as Niger and TSADDA in 1885 with a Map and Appendices. http://ia600303.us.archive.org/. John Mueray, Albemarle Street (published with a sanction of Her Majesty's Government).

Igboland. Wikipedia. https://en.wikipedia.org/wiki/Igboland

Isichei, E. (1983). A History of Nigeria. Essex. UK: Longman Group Limited.

Onwutalobi, A. C. (2015) History of Otolo Nnewi. http://www.nnewi.info/component/k2/item/104-history-of-otolo-nnewi

Oriji, N. J. (1994). Traditions of Igbo Origin: A Study of Pre-Colonial Population Movements in Africa. New York: P. Lang.

Slattery, K. (2010). The Igbo People-Origins \& History. MA Degree in Modern Literary Studies, Belfast: Queens's Univ.

Talbot, P. A. (1926). The Peoples of Southern Nigeria (Vol. 4). London: Oxford. 


\section{Further Reading}

Isichei, E. (1976). A History of the Igbo People. London: Macmillan.

Klein, N. (2007). The Shock Doctrine: The Rise of Disaster Capitalism. Toronto: Vintage Canada.

Lebakeng, T. (2010). Discourse on Indigenous Knowledge Systems, Sustainable Socio-Economic Development and the Challenge of the Academy in Africa. CODESRIA Bulletin, Nos. 1\&2, 24.

Mbeke-Ekanem, T. (2000). Beyond the Execution: Understanding Ethnic and Military Politics in Nigeria. California: Inland Publication Company.

Mudimbe, V. (1988). The Invention of Africa: Gnosis, Philosophy, and the Order of Knowledge. Indianapolis: Indiana University Press.

Ngugi, WaThiong'o (2005). Decolonizing the Mind: The Politics of Language in African Literature. Studies in African Literature. Oxford: James Currey Ltd.

Nwabueze, B. O. (1995). Crises and Problems in Education in Nigeria. Ibadan: Spectrum Books Limited.

Rodney, W. (1973). How Europe Underdeveloped Africa. London: Bogle-L’Ouverture Publications.

Uchendu, V. C. (1965). The Igbo of Southeast Nigeria. New York: Holt. 